Yüzüncü Y1 Üniversitesi
Tarim Bilimleri Dergisi

Araştırma Makalesi (Araştırma Makalesi)

\title{
Van Gölü Havzasından Toplanan Terslale (Fritillaria imperialis L.) Genotiplerinde Genetik Farklılığın iPBS Retrotranspozon Markırları ile Belirlenmesi
}

\section{Metin KOÇAK ${ }^{1}$, Merve Dilek KARATAŞ ${ }^{2}$, Şevket ALP ${ }^{3}$, Faheem Shehzad BALOCH ${ }^{4}$, Mehtap YILDIZ*5}

\footnotetext{
1,2,5Van Yüzüncü Y1l Üniversitesi, Ziraat Fakültesi, Tarımsal Biyoteknoloji Bölümü, 65040, Van, Türkiye ${ }^{3}$ Van Yüzüncü Yıl Üniversitesi, Mimarlık ve Tasarım Fakültesi, Peyzaj Mimarlığı Bölümü, 65040, Van, Türkiye ${ }^{4}$ Bolu Abant İzzet Baysal Üniversitesi, Ziraat ve Doğa Bilimleri Fakültesi, Tarla Bitkileri Bölümü, 14000, Bolu, Türkiye

${ }^{1}$ https://orcid.org/0000-0002-8109-5245 ${ }^{2}$ https://orcid.org/0000-0002-1076-3648 ${ }^{3}$ https://orcid.org/0000-0002-9552-4848 ${ }^{4}$ https://orcid.org/0000-0002-7470-0080 ${ }^{5}$ https://orcid.org/0000-0001-6534-5286 *Sorumlu yazar e-posta: mehtapyildiz@gmail.com
}

\section{Makale Bilgileri}

Geliș: 18.03 .2020

Kabul: 29.05.2020

Online Yayınlanma 30.06.2020

DOI: 10.29133/yyutbd.705721

\section{Anahtar kelimeler}

Fritillaria imperialis, Genetik varyasyon, iPBS-Retrotranspozon.
Öz: Fritillaria imperialis L. (Terslale) Türkiye'de doğal olarak yetişen ve süs bitkisi olarak kullanılan bir türdür. Bu tür doğada morfolojik olarak yüksek bir genetik varyasyon göstermektedir. Van Gölü havzasından toplanan $74 \mathrm{~F}$. imperialis genotipi arasındaki genetik çeşitliliği belirlemek amacıyla yürütülen bu çalışmada, 19 farklı iPBS-Retrotranspozon primeri kullanılmıştır. Kullanılan 19 primerin tamamı \%100 oranında polimorfizm gösteren toplam 94 bant oluşturmuştur. Primer başına düşen ortalama bant sayısının 4.94, ortalama polimorfizm bilgi içeriğinin (PIC) ise 0.58 olduğu belirlenmiştir. En düşük bant veren primer 2 bant oluştururken, en yüksek bant veren primer 10 bant oluşturmuştur. Ortalama etkili allel sayısının 1.50, Shannon bilgi indeksinin 0.47, gen çeşitliliğinin ise 0.30 olduğu saptanmıştır. Elde edilen sonuçlar, Van Gölü havzasından toplanan ters lale genotiplerindeki genetik farklılığın önemli düzeyde olduğunu ortaya koymuştur. Terslale genotiplerinde ilk kez iPBS-Retrotranspozon markırları kullanılarak genetik çeşitliliğin belirlenmesine yönelik olarak yürütülen bu çalışma, iPBS-Retrotranspozon markır sisteminin bu türde başarılı bir şekilde uygulanabileceğini ortaya koymuştur. Elde edilen veriler, terslale üzerinde yürütülecek ıslah çalışmaları için ön bilgi oluşturacak niteliktedir.

\section{Identification of Genetic Variations on Fritillaria imperialis L. Genotypes Collected from Van Lake Basin by iPBS-Retrotranspozon Markers}

\section{Article Info}

Received: 18.03.2020

Accepted: 29.05.2020

Online Published 30.06.2020

DOI: 10.29133/yyutbd.705721

\section{Keywords}

Fritillaria imperialis, Genetic diversity, iPBS-retrotransposons.

\begin{abstract}
Fritillaria imperialis L. naturally grows in Turkey and it is used as an ornamental plant. This species harbored plentiful genetic variation for various morphological traits in its natural habitat. In this study, 19 different iPBSRetrotransposon primers were used to identify genetic variation among $74 \mathrm{~F}$. imperialis genotypes collected around Van lake basin. 19 primers amplified 94 bands, $100 \%$ polymorphism. The average number of bands per primer was 4.94 and the average polymorphism information content (PIC) was 0.58. Maximum number of polymorphic bands were 10 while the minimum number of polymorphic bands were 2 . The mean effective number of alleles, Shannon information index and the gene diversity were $1.50,0.47$, and 0.30 respectively. The results reflected that genetic variations of $F$. imperialis genotypes collected from Van lake basin were significant. This is the first report identifying the genetic
\end{abstract}


variations of $F$. imperialis genotypes by iPBS-Retrotransposon primers, and it proved that iPBS-Retrotransposon marker system could be applied successfully in $F$. imperialis for genetics and genomic studies. The data obtained from this study will provide preliminary information for future $F$. imperialis breeding activities.

\section{Giriş}

Dünyada Meryemin gözyaşları olarak bilinen Fritillaria imperialis L. türü ülkemizde Terslale, Ağlayan gelin, Şahtuğu (Tuğu şahi), Kral lalesi, Şerefeli lale, Gülnahun, Şemdinli lalesi veya Hakkari lalesi olarak bilinmektedir. Çok yıllık olan bu tür süs bitkileri sektörü yanında tıbbi amaçlarla da kullanılmaktadır (Alp, 2006; Rahimi ve ark., 2013).

F. imperialis, Türkiye'den Viyana'ya götürüldüğü 400 yıldan daha fazla zamandan beri Batı Avrupa'da "Crown imperial” olarak bilinmesine karşılık, İran ve Orta Doğu sanatında çok daha önceden bilinmektedir. Tür Avrupa'da tanıtıldıktan sonraki 100 yıl içinde soğuklara dayanıklı temel otsu bitkiler arasına girmiştir (Clark ve ark., 2003). F. imperialis'in doğal popülasyonları Türkiye'de geniş bir alana yayılmış olup; başta Kahramanmaraş, Siirt, Şırnak, Van, Bitlis ve Hakkâri illeri olmak üzere, genellikle 1200-2500 m arasındaki yüksekliklerdeki dağ yamaçları ve çalılıklarda yayılış göstermektedir. $F$. imperialis türü, etkileyici çiçeklerinden dolayı kültüre alınmış ve başta Hollanda olmak üzere doğadan toplanarak birçok Avrupa ülkesine ihracatı yapılmaktadır (Davis, 1984; Arslan ve Sarıhan, 2002; Alp, 2006; Tekşen ve Aytaç, 2011). Terslale soğanları diüretik, yumuşatıcı, çözücü özelliklere sahiptir ve ayrıca taze bitkiler toksik alkaloid olan "imperialine” içermektedir. Soğanlanı içerdikleri steroidal alkaloitler sayesinde modern tıpta ilaç sanayinde kullanma potansiyeli bulunmaktadır (Bingöl ve ark., 1996).

Genetik çeşitlilik değişen çevresel değişikliklere uyum ve türlerin uzun süre hayatta kalmaları için oldukça önemlidir. Türler arasındaki genetik çeşitliliğin korunması da önemli hedeflerdendir; çünkü genetik varyasyonun azlığının popülasyonların çevre şartlarına uyum yeteneğini azalttığı düşünülmektedir (Chaleshtori ve ark., 2012; Barut ve ark., 2020). F. imperialis türünün iklim değişikliğinde neslinin devam edip etmeyeceğine yönelik genetik çeşitliliğe sahip olup olmadığ önemli bir sorudur. Türün korunması için gerekli olan bilgi popülasyon genetik çalışmaları sayesinde sağlanır.

DNA'ya dayalı moleküler markırlar üzerine kapsamlı araştırmalar tüm dünyada devam etmektedir. Moleküler markırlar genetik çeşitliliği tespit etmek için yaygın olarak kullanılmaktadır (Akçalı-Giachino ve İnan, 2019). Genetik çeşitliliği korumak için çeşitli DNA markırları arasında retrotranspozon markırları genel uygulanabilirlik, basit uygulanma ve genetik kararlılık özellikleri ile çok sayıda evrimsel ve genetik çalışmada geniş çapta uygulanmıştır. Retrotranspozonlar kısa evrim periyodunda yüksek sayıda kopya üreten ve bitki genomunun evrimsel yapısının önemli bir bileşeni olabilen en çok değişken genomik faktörlerden birini sunmaktadır. Retrotranspozonlar ökaryot hücrelerde özellikle bitki türlerinde genom boyunca bol miktarda bulunmaktadır (Finnegan, 1989). Bitki genomları retrotranspozon içerikleri açısından farklılık gösterirler ve sıklıkla bitki genomunun \%50'sini oluşturmakta hatta bu oran \%90'lara kadar çıkabilmektedir (San Miguel ve ark., 1996). Retrotranspozonların bol bulunmaları ve kendilerini genomun diğer bölgelerine eklemeleri farklı grup organizmalardaki farklı popülasyonlar için güçlü bir DNA markır olmalarını sağlamaktadır (Zampicinini ve ark., 2004). Primer arası bağlanma bölgesi (iPBS) sekans bilgisi gerektirmeyen güçlü bir DNA parmak izi tekniği olarak ispatlanmıştır ve evrensel markır sistemi olarak tercih edilmektedir.

F. imperialis'de genetik çeşitliliği belirlemek amacıyla RAPD, ISSR ve AFLP markırları önceden test edilmiştir. Ancak iPBS-retrotranspozon markırları bu türde daha önce test edilmemiştir. $\mathrm{Bu}$ çalışmada; 1) Van Gölü havzasında toplanan çiçek rengi, çiçek sayısı, bitki boyu, kahkül yapısı farklı olan terslalelerin kendi aralarındaki yakınlık düzeylerinin belirlenmesi, 2) Aynı bölgeden toplanmış olan ve doğal olarak yetişen terslalelerde tohum ile çoğalmadan kaynaklı açılım düzeyinin belirlenmesi, 3) Terslalede daha önce çalışılmamış iPBS retrotranspozon markır tekniğinin verimliliğinin test edilmesi, 4) DNA analizlerinin değerlendirilmesi sonucunda, daha sonra yapılabilecek projelerde ıslah amaçlarına uygun ve farklı ebeveynler seçerek melezleme yapmak ve genetik haritalama çalışmaları için popülasyon geliştirmek amaçlanmıştır. 


\section{Materyal ve Yöntem}

\subsection{Bitki materyali ve DNA izolasyonu}

Çalışmada bitkisel materyal olarak kullanılan 74 adet terslale genotipi Van Gölü havzasında 5 farklı lokasyondan toplanmış ve 2012 yılında Van Yüzüncü Yıl Üniversitesi'nde açıkta tarla koşullarına dikilmiştir. Bitki DNA'ları her terslale genotipine ait genç yapraklardan izole edilmiştir. DNA izolasyonunda Doyle ve Doyle (1990) tarafindan bildirilen yöntemde Boiteux ve ark. (1999) tarafından yapılan minor modifikasyonu kullanılmıştır. DNA konsantrasyonları NanoDrop (Thermo Nanodrop 2000) ile ölçülmüş ve iPBS retrotranspozon markır tekniği için $25 \mathrm{ng} / \mu \mathrm{l}$ 'ye seyreltilmiştir. Çalışmada kullanılan terslale genotiplerinin toplandığı lokasyonlara ait bilgiler Çizelge 1'de verilmiştir.

Çizelge 1. Van Gölü Havzasında toplanan terslale genotiplerinin lokasyon bilgileri

\begin{tabular}{llcccc}
\hline & \multicolumn{1}{c}{ Toplanan Bölge } & Rakım $(\mathrm{m})$ & Enlem & Boylam & Genotip sayıs \\
\hline 1 & Aydınocak Köyü & 1923 & $38311699 \mathrm{D}$ & $4254654 \mathrm{~K}$ & 21 \\
2 & Dilmetaş Köyü & 1802 & $38321690 \mathrm{D}$ & $4254650 \mathrm{~K}$ & 23 \\
3 & Kurutlu Köyü & 1849 & $38319107 \mathrm{D}$ & $4253894 \mathrm{~K}$ & 8 \\
4 & Gökbudak Köyü & 1986 & $37540017 \mathrm{D}$ & $4239351 \mathrm{~K}$ & 13 \\
5 & Doğanyayla Köyü & 1980 & $38300325 \mathrm{D}$ & $4220099 \mathrm{~K}$ & 9 \\
\hline
\end{tabular}

\section{3. iPBS-Retrotranspozon analizleri}

Çalışmada, Kalendar ve ark. (2010) tarafindan üretilen ve evrensel olarak belirtilen iPBS retrotranspozon DNA moleküler markırları kullanılmıştır. iPBS retrotranspozon primerleri rastgele seçilen 8 terslale genotipinde denenmiş; en fazla amplifikasyon ve polimorfizm gösteren primerler seçilmiştir. Tarama sonucunda en polimorfik bulunan 19 adet iPBS retrotranspozon primeri tüm terslale genotiplerinin moleküler karakterizasyonunda kullanılmıştır. Çalışmada kullanılan primerlerin kodları, sekans bilgileri ve bağlanma sıcaklıkları Çizelge 2'de verilmiştir. iPBS retrotranspozon analizleri Kalendar ve ark. (2010)'na göre yapılmıştır. PZR (Polimeraz Zincir Reaksiyonu); $25 \mu \mathrm{l}$ reaksiyon karışımında, 25-50 ng DNA, 1 X DreamTaq PZR buffer (Fermentas), $1 \mu \mathrm{M}$ primer (12-13 nükleotid primerleri için) veya $0.6 \mu \mathrm{M}$ (18 nükleotid primerler için), $0.2 \mathrm{mM}$ dNTPs, 1 ünite Taq DNA polimeraz (Fermentas) ve 0.04 ünite Pfu DNA polimeraz (Fermentas) içermektedir. PZR programi; önce $95^{\circ} \mathrm{C}$ 'de 4 dakika denatürasyon ile başlamış ve 30 döngü $95^{\circ} \mathrm{C}$ 'de 15 saniye denatürasyon, $50-65^{\circ} \mathrm{C}$ 'de 1 dakika bağlanma (primere bağlı olarak değişmek üzere), $68^{\circ} \mathrm{C}$ 'de 1 dakika ve son uzama safhas $72{ }^{\circ} \mathrm{C}$ 'de 5 dakikadan oluşmaktadır. iPBS analizleri için elde edilen PZR ürünleri 1xTBE tampon çözeltisi kullanılarak ethidyum bromür içeren \%1.7'lik agaroz jelde koşularak, UV 1şık altında fotoğrafları çekilmiştir. Jelde öncü olarak 100 baz çiftlik DNA kullanılmış, değerlendirmeler buna göre yapılmıştır. 
Çizelge 2. Çalışmada kullanılan primer kodları, sekansları ve bağlanma sıcaklıkları

\begin{tabular}{ccc}
\hline Primer Kodu & Sekans $\left(5^{\prime}-3{ }^{\prime}\right)$ & Bağlanma Sicaklığ $\left({ }^{\circ} \mathrm{C}\right)$ \\
\hline iPBS2076 & GCTCCGATGCCA & 60 \\
iPBS2077 & CTCACGATGCCA & 55 \\
iPBS2232 & AGAGAGGCTCGGATACCA & 55 \\
iPBS2239 & ACCTAGGCTCGGATGCCA & 55 \\
iPBS2078 & GCGGAGTCGCCA & 63 \\
iPBS2079 & AGGTGGGCGCCA & 65 \\
iPBS2080 & CAGACGGCGCCA & 63 \\
iPBS2374 & CCCAGCAAACCA & 53 \\
iPBS2375 & TCGCATCAACCA & 50 \\
iPBS2377 & ACGAAGGGACCA & 53 \\
iPBS2378 & GGTCCTCATCCA & 53 \\
iPBS2394 & GAGCCTAGGCCA & 55 \\
iPBS2249 & AACCGACCTCTGATACCA & 51 \\
iPBS2251 & GAACAGGCGATGATACCA & 53 \\
iPBS2270 & ATCCTGGCAATGGAACCA & 55 \\
iPBS2295 & AGAACGGCTCTGATACCA & 60 \\
iPBS2395 & TCCCCAGCGGAGTCGCCA & 53 \\
iPBS2415 & CATCGTAGGTGGGCGCCA & 60 \\
iPBS2270 & GCATGGCCTCCA & 53 \\
\hline
\end{tabular}

\section{4. İstatistiksel analiz}

Seçili primerlerin her biri için PZR amplifikasyonu tekrarlanarak retrotranspozon markır sistemi için DNA profillerinin tekrarlanabilirliği test edilmiştir. Sadece güçlü ve temiz bantlar analiz için dikkate alınmıştır. iPBS-retrotranspozon bantları ikili skorlama sistemine göre bant varlığında "1" yokluğunda "0" olarak analiz edilmiştir. Parlak ve diğerlerinden net şekilde ayrılmış bantlar skorlanmıştır, zayıf bantlar yapay bantların skorlanmasını önlemek için dikkate alınmamıştır. Polimorfizm bilgi içeriği De Riek ve ark., 2001'nın bildirmiş olduğu formüle göre hesaplanmıştır;

$$
P I C i=2 \mathrm{fi}(1-\mathrm{fi})
$$

Formülde; fi: çoğalmış allellerin (bant mevcut) frekansını, (1-fi) ise; boş allellerin (bant mevcut değil) frekansını ifade etmektedir. Dendrogramlar Neighbor Net (NNet) Nei genetik mesafe (Nei, 1987) kullanılarak Splits Tree v4.11 (Huson ve Bryant, 2006) programı ile oluşturulmuştur.

Doksandört terslale genotipindeki genetik farklılığ araştırmak için kullanılan etkili allel sayısı (Ne), gen çeşitliliği (h), Shannon bilgi indeksi (I) parametreleri Popgene ver. 1.32 (Yeh ve ark. 2000) ile hesaplanmıştır.

\section{Bulgular}

Seksen üç iPBS primerinin tamamı rastgele seçilmiş 4 adet terslale genotipinde denenmiştir. Devam eden analizler için net ve tekrar edilebilir bant profiline sahip 19 primer seçilmiştir. Belirtilen 19 primer 74 terslale genotipinde denenmiş, tamamı polimorfik olmak üzere toplam 94 adet skorlanabilir bant üretmiştir. Primer başına düşen retrotranspozon bant sayısı, ortalama 4.94 bant olmak üzere 2 (RT2079, RT2232, RT2378) ile 10 (RT2076) arasında değişim göstermiştir. PIC değerleri 0.38 (RT2295) ile 0.97 (RT2232) arasında değişkenlik göstermiş, ortalama PIC değeri 0.58 olarak belirlenmiştir (Çizelge 3). Skorlanabilen tüm bantlar polimorfik olduğundan primer başına düşen ortalama polimorfik ve toplam polimorfik bant sayısı yukarıda verilen değerler ile aynıdır (4.94) (Çizelge 3). En düşük genetik uzaklık 0.102 ile YYU54 ve YYU56 genotipleri arasında belirlenirken en yüksek genetik uzaklık 1.00 ile YYU63 ve 25 terslale genotipi (YYU1, YYU2, YYU5, YYU6, YYU9, YYU10, YYU11, YYU12, YYU13, YYU14, YYU19, YYU20, YYU21, YYU23, YYU24, YYU28, YYU32, YYU46, YYU48, YYU53, YYU54, YYU55, YYU57, YYU73, YYU74) arasında görülmüştür. 
Etkili allel sayıs1 (Ne) en yüksek iPBS2239 primerinde (1.73), en düşük ise iPBS2270 primerinde (1.11) elde edilirken ortalama etkili allel sayısı 1.50 olarak bulunmuştur. Ortalama gen çeşitliliği (h) 0.30 iken; en yüksek gen çeşitliliği iPBS2239 primerinde 0.41 ; en düşük gen çeşitliliği iPBS2270 primerinde 0.10 olarak belirlenmiştir. Shannon bilgi içeriği (I) 0.20 (iPBS2270) ile 0.60 (iPBS2270) arasında farklılık gösterirken, ortalama değer 0.47'dir (Çizelge 3).

Çizelge 3. 19 iPBS markırının terslale genotiplerinde genetik çeşitlilik parametrelerinin değerlendirilmesi

\begin{tabular}{|c|c|c|c|c|c|c|c|}
\hline Lokus & $\mathrm{T}^{*}$ & $\mathrm{P}^{*}$ & $\mathrm{P} \%$ & PIC & $\mathrm{Ne}$ & $\bar{h}$ & I \\
\hline 2076 & 10 & 10 & 100 & 0.49 & 1.59 & 0.34 & 0.50 \\
\hline 2077 & 5 & 5 & 100 & 0.39 & 1.52 & 0.31 & 0.47 \\
\hline 2078 & 8 & 8 & 100 & 0.60 & 1.70 & 0.39 & 0.57 \\
\hline 2079 & 2 & 2 & 100 & 0.75 & 1.52 & 0.33 & 0.50 \\
\hline 2080 & 3 & 3 & 100 & 0.84 & 1.34 & 0.22 & 0.36 \\
\hline 2232 & 2 & 2 & 100 & 0.97 & 1.54 & 0.35 & 0.53 \\
\hline 2239 & 6 & 6 & 100 & 0.77 & 1.73 & 0.41 & 0.60 \\
\hline 2249 & 4 & 4 & 100 & 0.54 & 1.53 & 0.32 & 0.49 \\
\hline 2251 & 4 & 4 & 100 & 0.70 & 1.52 & 0.31 & 0.49 \\
\hline 2270 & 3 & 3 & 100 & 0.71 & 1.11 & 0.10 & 0.20 \\
\hline 2295 & 5 & 5 & 100 & 0.38 & 1.33 & 0.21 & 0.35 \\
\hline 2374 & 6 & 6 & 100 & 0.56 & 1.50 & 0.32 & 0.50 \\
\hline 2375 & 3 & 3 & 100 & 0.70 & 1.51 & 0.33 & 0.51 \\
\hline 2377 & 5 & 5 & 100 & 0.43 & 1.48 & 0.29 & 0.45 \\
\hline 2378 & 2 & 2 & 100 & 0.95 & 1.41 & 0.26 & 0.42 \\
\hline 2383 & 6 & 6 & 100 & 0.75 & 1.68 & 0.38 & 0.56 \\
\hline 2394 & 7 & 7 & 100 & 0.40 & 1.53 & 0.31 & 0.48 \\
\hline 2395 & 6 & 6 & 100 & 0.58 & 1.50 & 0.31 & 0.48 \\
\hline 2415 & 7 & 7 & 100 & 0.49 & 1.62 & 0.35 & 0.52 \\
\hline Toplam & 94 & 94 & & & & & \\
\hline Ortalama & 4.94 & 4.94 & 100 & 0.58 & 1.50 & 0.30 & 0.47 \\
\hline
\end{tabular}

PIC: polimorfizm bilgi içeriği, Ne: etkili allel sayısı, h: gen çeşitliliği I: Shannon bilgi indeksi.

Analizler sonucu 74 terslale genotipinin iki ana gruba ayrıldı̆̆ görülmektedir (Şekil 1). İlk grup (A) yalnızca tek genotipten (YYU 63 no’lu genotip) oluşurken, ikinci grup (B) 73 genotipten oluşmuştur. B grubu B1, B2, B3, B4, B5 ve B6 olmak üzere 6 farklı gruba ayrılmıştır. Bu gruplardan B1 6 adet genotip içerirken, B2 4 adet, B3 14 adet, B4 13 adet, B5 16 adet ve B6 20 adet genotip içermektedir. Belirtilen 6 grupta kendi içinde farklı alt gruplara ayrılmıştır. Çalışmada kullanılan 74 genotipin 57 adeti (YYU1, YYU2, YYU3, YYU4, YYU5, YYU6, YYU7, YYU8, YYU9, YYU10, YYU11, YYU12, YYU14, YYU15, YYU16, YYU17, YYU18, YYU19, YYU20, YYU22, YYU23, YYU24, YYU25, YYU27, YYU28, YYU30, YYU31, YYU33, YYU37, YYU38, YYU39, YYU40, YYU41, YYU42, YYU44, YYU45, YYU46, YYU47, YYU50, YYU51, YYU52, YYU53, YYU55, YYU57, YYU58, YYU59, YYU63, YYU64, YYU65, YYU66, YYU67, YYU68, YYU69, YYU71, YYU72, YYU73, YYU74) kırmız1, 5 adeti (YYU34, YYU36, YYU48, YYU54, YYU56) sar1, 1 adeti (YYU49) turuncu renkli çiçeklere sahipken, geriye kalan 11 adet genotip (YYU13, YYU21, YYU26, YYU29, YYU32, YYU35, YYU43, YYU60, YYU61, YYU62, YYU70) çiçek oluşturmadan kurumuştur. Sarı çiçek rengine sahip YYU34 ve YYU36 nolu genotipler B3 grubuna ait alt gruplardan birini oluşturmuştur. Sarı renge sahip diğer üç genotipten iki adeti de (YYU54 ve YYU 56) B6 grubuna ait alt gruplardan birini oluşturmuştur. Sarı çiçek rengine sahip olan diğer genotip (YYU49) ise YYU54 ve YYU56 genotipleri ile aynı grupta (B6) yer almasına rağmen, diğer sarı renkli çiçek yapısına sahip genotipler ayrı alt grupta yer almıştır. Turuncu çiçek rengine sahip genotip (YYU49) B1 grubunda yer almıştır (Şekil 2.). Kırmızı çiçek rengine sahip genotipler bütün gruplara dağılmıştır. Sarı çiçek rengine sahip genotiplerin farklı gruplara ait alt gruplarda bulunması, çalışma sonuçlarının çiçek rengi açısından genotipler arasındaki farklılıkları belirlemede yeterince ayırt edici olmadığını göstermektedir. Benzer şekilde diğer morfolojik kriterler de (yaprak; en-boy, gövde; tüm boy, sap uzunluğu, sap çap1, kandil; sayı-petal boyu, petal eni ve kakül yaprak sayısı) değerlendirildiğinde genotipler arasında farklılığın tespit edilemediği görülmektedir. Bu durumun kullanılan primer sayısının az olması, tek markır tekniğinin kullanılması ve çalışmada 
kullanılan popülasyon içinde kendi aralarında tozlanmalar sonucu genotipler arasında genetik olarak karışımların meydana gelmiş olmasından kaynaklandığı düşünülmektedir.

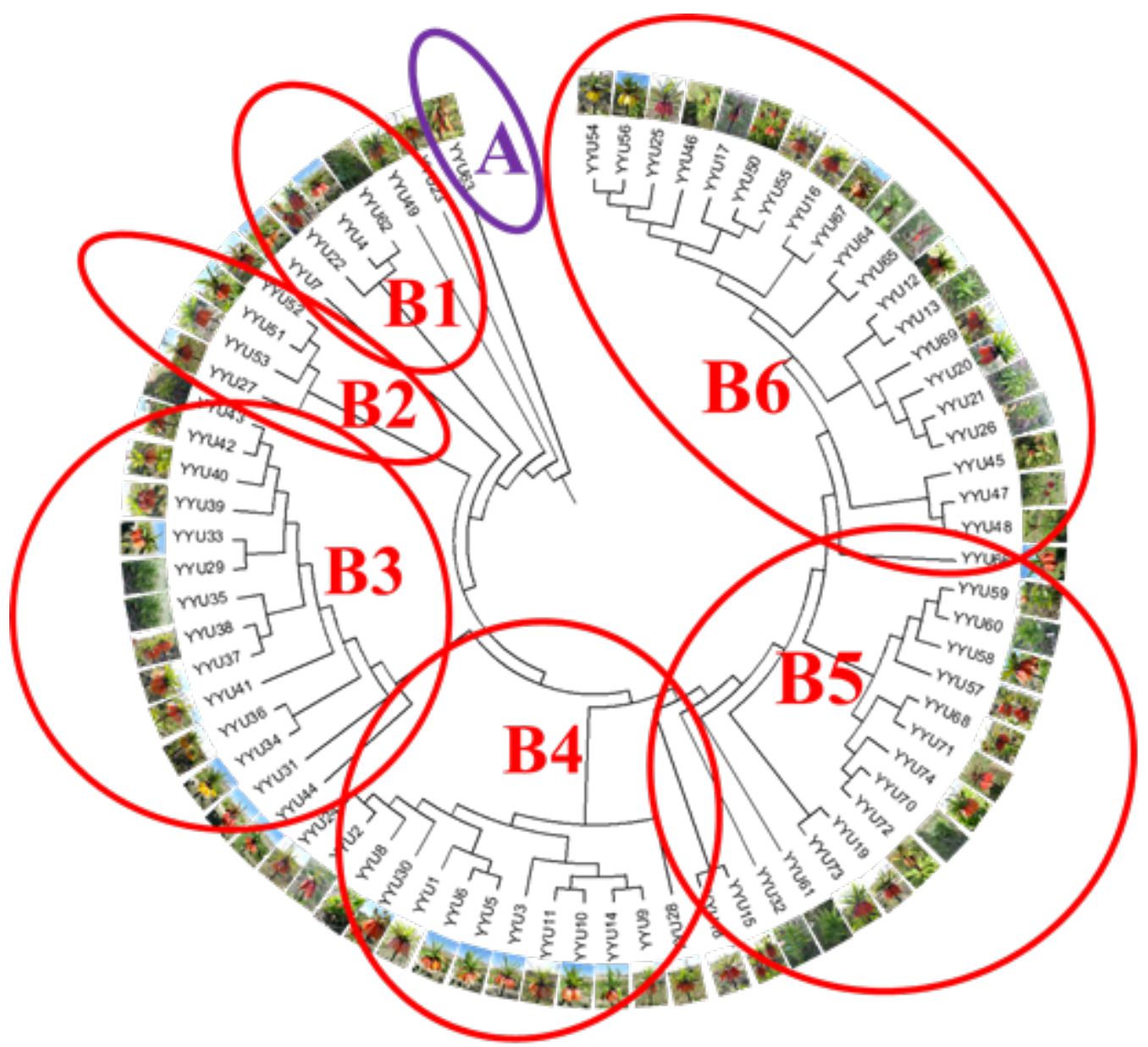

Şekil 1. iPBS-retrotranspozon markırlerı ile oluşturulmuş 74 terslale genotipine ait dendogram.

\section{Tartışma ve Sonuç}

Terslale dahil birçok türde bitki genom analizleri önemli ölçüde çeşitlilik gösterebilen markır sistemleri kullanarak farklı çeşitler/türler arasındaki ilişkiyi sunmaktadır. Farklı markır teknolojileri farklı genomik bölgeleri çoğaltabilir. Çeşitli DNA markırları arasında retrotranspozon markırları genel uygulanabilirlik, basit uygulanma ve genetik kararlılık özellikleri ile çok sayıda evrimsel ve genetik çalışmada geniş çapta uygulanmıştır. Retrotranspozonlar kısa evrim periyodunda yüksek sayıda kopya üreten ve bitki genomunun evrimsel yapısının önemli bir bileşeni olabilen en çok değişken genomik faktörlerden birini sunmaktadır. Retrotranspozonlar ökaryot hücrelerde özellikle bitki türlerinde genom boyunca bol miktarda bulunmaktadır (Finnegan, 1989). Bu özelliklerinden dolayı çalışmada, iPBS markır sistemi kullanılmıştır. Fritillaria türlerinde bugüne kadar RAPD, ISSR, AFLP ve SSR markır teknikleri uygulanmıştır. Ancak bu türde iPBS-Retrotranspozon markır tekniği ilk olarak bu çalışmada kullanılmıştır. Çalışmada Van Gölü havzasından toplanan 74 adet terslale genotipi iPBSRetrotranspozon primerleri ile analiz edilmiştir. Analizlerde 19 iPBS-Retrotranspozon primeri kullanılmış ve skorlanabilir tamamı polimorfik olan 94 adet bant üretilmiştir. Primer başına ortalama bant sayıs1 4.94 olup en düşük bant sayısı 2, en yüksek bant sayıs1 10 olmuştur ve tüm primerler $\% 100$ polimorfizm göstermiştir. Chaleshtori ve ark. (2012), aynı türde AFLP, ISSR ve RAPD markır teknikleri ile sırasıyla \% 99.5, \% 80.53 ve \% 83.2 polimorfik bant elde etmişlerdir. Elde edilen sonuçlar, bu sonuçlarla karşılaştırıldığında iPBS-Retrotranspozon markır sisteminin terslalede genetik çeşitliliğin tespiti için kullanılabileceğini göstermektedir. iPBS-Retrotranspozon markırları ile defne, biber ve nohutta genetik çeşitlilik üzerine çalışmalar yapılmış; polimorfik bant sayıları sırasıyla $\% 84.1, \% 92$, 
\%100 olarak belirtilmiştir (Karık ve ark. 2019, Yıldız ve ark. 2019, Andeden ve ark. 2012). Terslale üzerine yürütülen bu çalışmada ise, polimorfik bant sayısı \%100 olarak bulunmuştur. Bu oran iPBSRetrotranspozon markır sisteminin terslalede genetik çeşitliliği belirlemede başarılı olduğunu göstermektedir.

PIC değeri, genetik çeşitliliğin belirlenmesinde, polimorfik lokusların etkinliğinin anlaşılmasında ve markırın genotipler arasındaki ayrım gücünün belirlenmesinde kullanılmaktadır. Terslale genotipleri üzerine yürütülen bu çalışmada, PIC değeri 0.38-0.97 arasında değişkenlik gösterirken, ortalama PIC değeri 0.58 olarak saptanmıştır. iPBS markırları ile biber (Yıldız ve ark. 2019), defne (Kark ve ark. 2019, nohut (Andeden ve ark. 2012), bezelye (Baloch ve ark. 2015), tütün (Yaldız ve ark. 2018), bamya (Yıldız ve ark. 2015) türlerinde yapılan çalışmalar, bu markır tekniğinin güvenilir olduğunu ve genetik farklılığın belirlenmesinde kullanılabileceğini ortaya koymaktadır. Önceki çalışmalarla, iPBS-Retrotranspozonların yüksek oranda tekrarlanabilir, sağlam ve güvenilir bir markır sistemi olduğu ortaya konulmuş (Kalendar ve ark. 2010, Guo ve ark. 2014) ve bu sonuçlar diğer markır sistemleriyle de kıyaslanarak kanıtlanmıştır. Xu ve ark. (2018), Tetradium ruticarpum türünde ISSR ve iPBS markırları ile genetik farklılığı incelemişler ve iPBS markırlarının ISSR markır tekniğine göre daha fazla polimorfizm gösterdiğini belirtmişlerdir. Benzer şekilde pirinçte SSR ve iPBS markırları ile popülasyon yapısını inceleyen Cömertpay ve ark. (2016)'da her iki markırın benzer sonuçlar verdiğini bildirmişlerdir. Bu sonuçlar da dikkate alındığında, iPBS markırlarının yüksek oranda tekrarlanabilirliği, düşük maliyet ve güvenilirlik gibi özellikleriyle genetik çeşitlilik araştırmalarında kullanılabileceğini ortaya koymaktadır.

Van Gölü havzasında yayılış gösteren terslale genotiplerinde genetik çeşitliliği belirlemek için farklı parametreler hesaplanmıştır (Çizelge 3). Bu parametrelerden biri olan maksimum etkili allel sayısı $(\mathrm{Ne})$; büyük genetik varyasyonların durumunu gösterir. Bu çalışmada, ortalama etkili allel sayısı 1.50 olarak bulunmuştur. Bu sonuç, iPBS markırları ile yapılmış çalışmalarda bildirilen değerlerden yüksektir (Karık ve ark. 2019, Yıldız ve ark. 2019, Yaldız ve ark. 2018). Diğer bir parametre olan ortalama gen çeşitliliğini (h) ise, Yıldız ve ark. (2019) 0.09 olarak belirlerken, Yaldız ve ark. (2018) 0.19 olarak belirlemişlerdir. Terslale genotiplerinde yürütülen bu çalışmada ise, ortalama gen çeşitliliği 0.30 olarak belirlenmiştir. Bu sonuç; çalışmada kullanılan genotiplerdeki genetik çeşitliliğin daha fazla olduğunu ortaya koymaktadır. Shannon bilgi indeksi, popülasyondaki varyasyonu ayırt etmede kullanılan bir diğer parametredir. Bu çalışmada ortalama Shannon bilgi indeksi 0.47 olarak saptanmıştır. Bu değer; önceki çalışmalarda bildirilen değerlerden daha yüksektir (Yıldız ve ark. 2019, Yaldız ve ark. 2018, Karı ve ark. 2019).

Genotipler arasındaki en düşük genetik mesafe 0.102 ile YYÜ54 ve YYÜ 56 nolu genotipleri arasında bulunmuştur. Bu iki genotip B6 grubunda yer almıştır (Şekil 2). Terslalede daha önce AFLP, ISSR, RAPD markırlarıyla yapılan çalışmada, 3 ana grup oluşmuş ve grupların da kendi aralarında alt gruplara ayrıldığı gözlenmiştir. Oluşan gruplarda aynı bölgeden alınan genotiplerin aynı grupta yer aldığ 1 belirtilmiştir (Chaleshtori ve ark. 2012).

Çalışmaya konu olan terslale genotiplerinin bazı morfolojik özellikleri (yaprak eni ve boyu, bitki boyu, sap uzunluğu ve sap çapı, kandil sayısı, petal boyu ve petal eni, kakül yaprak sayısı ve çiçek rengi) de belirlenerek yapılan genetik analiz sonuçları ile ilişkilendirilmeye çalışılmıştır. Sarı çiçek rengine sahip genotiplerin ikişerli gruplar halinde toplanması kullanılan markır sisteminin bu türde başarılı olduğunu göstermektedir. Nitekim bu genotiplerden ikisi (YYÜ54 ve YYÜ56) yapilan analizler sonucu en düşük genetik uzaklığa sahip olan genotipler olarak tespit edilmiştir. Sarı çiçekli genotiplerin hepsinin bir grup altında değil de ikişerli olarak farklı gruplar altında toplanmasının sebebinin ise sadece çiçek rengi ile ilgili bölgelerin çoğaltımının yapılmayıp farklı özelliklerle de bağlantılı bölgelerin çoğaltımının yapılmasından kaynaklandığı düşünülmektedir. Benzer şekilde YYÜ65 nolu genotip diğer tüm genotiplerden ayrilarak A grubunu oluşturmaktadır. İncelenen morfolojik değerler ele alındığında, YYÜ63 nolu genotipini diğer genotiplerden ayıran anlamlı bir farklılık görülmemiştir. Bu durum çoğaltımı yapılan bölgelerin incelenen morfolojik karakterlerle bağlantılı olmamasından kaynaklanabilir. Ayrıca bazı özellikler multigenik olduğundan dolayı morfolojik özellikler açısından YYÜ63 nolu genotip diğer genotiplerden belirli bir şekilde ayırt edilmemektedir. Ancak analizler sonucu bu genotipin diğerlerinden farklı bulunması anlamsız değildir, bu farklılığın incelenen morfolojik özellikler dışında farklı karakterlerden kaynaklandığ 1 düşünülmektedir. Çalışmada kullanılan terslale genotiplerinin tamamı Van Gölü havzasından toplanmıştır, farklı bölgelerden toplanan terslaleler ile daha anlamlı sonuçlar elde edilebileceğini düşünülmektedir. Her ne kadar 
morfolojik özellikler bakımından farklılıklar gözlemlense de gerek kendi aralarında tozlanmaları gerekse aynı havzadan toplanmaları nedeniyle ayırım çok anlamlı olmamıştır. Bu tür bir örneklemede primer sayısının artırılması ve daha farklı markır sistemlerinin (özellikle kodominant) kullanılması, belirtilen morfolojik özellikler açısından ayırt edici sonuçlar verebilir. Nitekim Yıldız ve ark. (2015), bamyada iPBS-retrotranspozon ve SSR markır sistemleri ile yaptıkları çalışmada tohum zarfı aynı renge sahip olan genotiplerin aynı gruplarda toplandıklarını bildirmişlerdir.

Çalışmada, Van Gölü çevresinde doğal olarak yetişen terslale genotiplerinden oluşan popülasyondaki genetik varyasyon iPBS-Retrotranspozon markır sistemi ile tespit edilmiştir. Elde edilen sonuçlar, iPBS-Retrotranspozon markır sisteminin birçok bitkide olduğu gibi terslale bitkisinde de başarılı bir şekilde kullanılabileceğini ortaya koymuştur. Çalışmanın sonuçları, terslale ıslahı için uygun ebeveynlerin seçiminde yardımcı olacak niteliktedir.

\section{Teşekkür}

Bu çalışma Van Yüzüncü Y1l Üniversitesi Bilimsel Araştırma Projeleri Koordinasyon birimi tarafindan desteklenmiştir (2015-HIZ-ZF328).

\section{Kaynakça}

Akçalı Giachino, R., \& İnan, D. (2019). Assessment of genetic diversity in Safflower (Carthamus tinctorius L.) using RAPD markers. YYU Journal of Agricultural Science, 29 (2): 300-308.

Alp, Ş. (2006). Doğal çiçek soğanlari, terslale koruma önlemleri ve yetiştiriciliği. Doğal Çiçek Soğancilarl Derneği, 2, 44.

Andeden, E. E., Baloch, F. S., Derya, M., Kilian, M., \& Özkan, H. (2012). iPBS-Retrotransposons-based genetic diversity and relationship among wild annual Cicer species. Plant Biochemsitry \& Biotechnology, 22, 453-466.

Arslan, N., \& Sarıhan, E. O. (2002). Türkiye'nin Fritillaria türleri ve bunların tarımı konusunda yapılan çalışmalar Paper presented at the II. Ulusal Süs Bitkileri Kongresi, Antalya.

Baloch, F. S., Alsaleh, A., de Miera, L. E. S., Hatipoğlu, R., Çiftçi, V., Karaköy, T., Yıldız, M., \& Özkan, H. (2015). DNA based iPBS-retrotransposon markers for investigating the population structure of pea (Pisum sativum) germplasm from Turkey. Biochemical Systematics and Ecology, 61, 244-252.

Barut, M., Nadeem, M. A., Karaköy, T., \& Baloch, F. S. (2020). DNA fingerprinting and genetic diversity analysis of world quinoa germplasm using iPBS-retrotransposon marker system. Turkish Journal of Agriculture and Forestry, 44.

Bingöl, F., Şener, B., Koyuncu, M., Faizi, S., \& Gilani, A. (1996). Biological activities of some Frittilaria L. species growing in Turkey. GUEDE-J Journal of Faculty of Pharmacy of Gazi University, 13(1), 45-49.

Boiteux, L. S., Fonseca, M. E. M., \& Simon, P. W. (1999). Effects of plant tissue and purification method on Randomly Amplified Polymorphic DNA-based genetic fingerprinting analysis in carrot. Journal of the American Society for Horticultural Science 124(1), 32-38.

Chaleshtori, B. S., Shiran, B., Kohgard, M., Mommeni, H., Hafizi, A., Khodombashi, M., Mirakhorli, N., \& Sorkheh, N. (2012) Assessment of genetic diversity and structure of Imperial Crown (Fritillaria imperialis L.) populations in the Zagros region of Iran using AFLP, ISSR and RAPD markers and implications for its conservation. Biochemical Systematics and Ecology, 42, 35-48.

Clark, T., \& Grey-Wilson, C. (2003). Crown Imperials. The Plantsman, 2, Part 1:33-47.

Cömertpay, G., Baloch, F. S., Derya, M., Andeden, E. E., Alsaleh, A., Sürek, H., Özkan, H. (2016). Population structure of rice varieties used in Turkish rice breeding programs determined using simple sequence repeat and inter-primer binding site- retrotransposon data. Genetics and Molecular Research, 15, 1-4.

Davis, P. H. (1984). Flora of Turkey and East Aegean Islands. Edinburgh, İSKOÇYA: Edinburgh University Press.

De Riek, J., Calsyn, E., Everaert, I., Van Bocksteal, E., \& De Loose, M. (2001). AFLP based alternative for the assessment of the distinctness, uniformity and stability of sugar beat varieties. Theoretical and Applied Genetics,103, 1254-1256. 
Doyle, J. J., \& Doyle, J. L. (1990) Isolation of plant DNA from fresh tissue. Focus, 12, 13-15.

Finnegan, D. J. (1989). Eukaryotic transposable elements and genome evolution. Trends in Genetics, 5, 103-107.

Guo, D. L., Guo, M. X., Hou, X. G., \& Zhang, G. H. (2014). Molecular diversity analysis of grape varieties based on iPBS markers. Biochemical Systematics and Ecology, 52, 27-32.

Gürlek, D. (2011). Studies on in vitro bulblet regeneration in Fritillaria imperialis L. and Fritillaria persica L. species. (phD), Ankara University, Institute of Natural and Applied Science Ankara, Turkey.

Huson, D. H., \& Bryant, D. (2006). Application of phylogenetic networks in evolutionary studies. Molecular Biology and Evolution, 23, 254-267.

Kalendar, R., Antonius, K., Smykal, P., \& Schulman, A. H. (2010). iPBS: a universal method for DNA fingerprinting and retrotransposon isolation. Theoretical and Applied Genetics, 121, 1419-1430.

Karık, Ü., Nadeem, M. A., Habyarimana, E., Ercişli, S., Yıldız, M., Yılmaz, A., Yang, S.H., Chung, G., \& Baloch, F.S. (2019). Exploring the genetic diversity and population structure of turkish laurel germplasm by the iPBS-Retrotransposon marker system. Agronomy-Basel, 9, 1-14.

Nei, M. (1987). Molecular Evolutionary Genetics. New York, USA: Columbia Univerisity Press, New York.

PopGene32. (2000). Based Freeware for Population Genetic Analysis, Version 1.32 for Windows. Yeh, F.C., Yang, R., Boyle, T.J., Ye, Z., Xiyan, J.M. PopGene32, Microsoft Windows-Based Freeware for Population Genetic Analysis, Version 1.32. Edmonton, Kanada. Mol. Biology and Biotechnology Centre, University of Alberta: Edmonton, AB, Canada, 2000.

Rahimi, M., Daneshvar M. H., Heidari, M., \& Yari, F. (2013). In vitro micropropagation of Fritillaria imperialis L. through induction of indirect organogenesis, International Journal of Agronomy and Plant Production, 4(3), 418-424.

San Miguel, P., Tikhonov, A., Jin, Y. K., Motchoulskaia, N., Zakharov, D., Berhan-Melake, A., Springer, P. S., Lee, M., Avramova, Z., \& Bennetzen, JL. (1996). Nested retrotransposons in the intergenic regions of the maize genome. Science, 274, 765-768.

Tekşen, M., \& Aytaç, Z. (2011). "The revision of the genus Fritillaria L. (Liliaceae) in the Mediterranean region (Turkey)”, Turkish Journal of BotanyTurk. J. Bot., 35, 447-478.

Xu, J. Y., Yan, Z., Y1, Z., Wu, G., Xie, G. Y., \& Qin, M. J. (2018). Molecular diversity analysis of Tetradium ruticarpum (WuZhuYu) in China based on inter-primer binding site (iPBS) markers and inter-simple sequence repeat (ISSR) markers. Chinese Journal of Natural Medicines, 16(1), $1-9$.

Yaldı, G., Camlıca, M., Nadeem, M. A., Nawaz, M. A., \& Baloch, F. S. (2018). Genetic diversity assessment in Nicotiana tabacum L. with iPBS-retrotransposons. Turkish journal of agriculture and forestry, 42, 154-164.

Yıldız, M., Koçak, M., \& Baloch, F. S. (2015). Genetic bottlenecks in Turkish okra germplasm and utility of iPBS retrotransposon markers for genetic diversity assessment. Genetics and Molecular Research, 14, 10588-10602.

Yıldız, M., Koçak, M., Nadeem, M. A., Cavagnaro, P., Barboza, K., Baloch, F. S., Argün, D., \& Keleş, D. (202019). Genetic diversity analysis in the Turkish pepper germplasm using iPBS (interprimer binding site) retrotransposon-based markers. Turkish Journal of Agriculture and Forestry, 43, 1-14.

Zampicinini, G., Blinov, A., Cervella, P., Guryev, V., \& Sella, G. (2004). Insertional polymorphism of a non-LTR mobile element (NLRCth1) in European populations of Chironomus riparius (Diptera, Chironomidae) as detected by transposon insertion display. Genome, 47, 1154-1163. 